\title{
THE RELATIONSHIPS BETWEEN THE ATP CONTENT OF PREIMPLANTATION MOUSE EMBRYOS AND THEIR DEVELOPMENT IN VITRO DURING CULTURE
}

\author{
P. QUINN* AND R. G. WALES \\ Department of Veterinary Physiology, University of Sydney, \\ Sydney, N.S.W. 2006, Australia
}

(Received 10th October 1972)

\begin{abstract}
Summary. A positive correlation was found between the levels of ATP in two-cell embryos from random-bred mice and the proportion of these embryos which developed to the blastocyst stage during culture in vitro. The better development of hybrid one-cell embryos to blastocysts than that of random-bred one-cell embryos may also be related to the higher amounts of ATP found in hybrid two-cell embryos cultured from the one-cell stage compared to those in embryos of the random-bred strain. The relationship between the ATP content of embryos and the proportion of embryos developing in vitro appeared to be different between the two groups of mice and was altered after culture in vitro.

The levels of ATP in two-cell embryos from random-bred strain and $F_{1}$ hybrid mice cultured from the one-cell stage in medium supplemented with glucose and serum albumin were higher than the levels of ATP in embryos cultured in glucose-free medium containing less albumin. During culture of hybrid one-cell embryos in the medium containing glucose and albumin, an effect of a low $\mathrm{O}_{2}$ tension in the atmosphere on ATP levels became apparent only after the morula stage.
\end{abstract}

\section{INTRODUCTION}

Various energy sources can support development of the mouse embryo in vitro at different stages of preimplantation development (Brinster, 1965a; Brinster \& Thomson, 1966). The levels of ATP in cultured mouse embryos are also affected by the source of energy available to the embryo, especially at the one- and two-cell stage of development (Quinn \& Wales, 1973). It would seem likely, therefore, that the developmental potential of an early embryo may be linked with its levels of ATP. Accordingly, the levels of ATP in both freshly collected two-cell mouse embryos and embryos which had been incubated for short periods in substrate-free medium to reduce their ATP content were measured and compared with the proportion of these embryos developing to the blastocyst stage in vitro.

By modification of the conditions of culture, one-cell embryos of certain

* Present address: The Jackson Laboratory, Bar Harbor, Maine 04609, U.S.A. 
strains of mice will also develop to the blastocyst stage (Whitten \& Biggers, 1968; Whitten, 1969, 1971). Therefore, the levels of ATP in cultured one-cell hybrid embryos which were capable of continued development were compared with those in embryos of random-bred mice which have been found to cleave once only when cultured from the one-cell stage (Whittingham \& Biggers, 1967).

\section{MATERIALS AND METHODS}

One- and two-cell mouse embryos were collected from female mice which had been induced to superovulate as previously described (Brinster, 1965b). Embryos were obtained either from mice of the randomly bred Quackenbush Special (QS) strain or from $F_{1}$ hybrid $\mathrm{C} 57 \mathrm{BL} \times \mathrm{CBA}$ female mice mated with QS males. The basic medium used was a modified Krebs-Ringer bicarbonate solution containing $25 \mathrm{~mm}$-DL-sodium lactate, $0.25 \mathrm{~mm}$-sodium pyruvate, $1 \mathrm{mg}$ bovine serum albumin $/ \mathrm{ml}, 60 \mu \mathrm{g}$ penicillin $/ \mathrm{ml}$ and $50 \mu \mathrm{g}$ streptomycin $/ \mathrm{ml}$ (Brinster, 1965c).

Where ATP determinations were made on freshly collected embryos, the embryos were washed twice $(2 \mathrm{ml} /$ wash) in basic medium. Embryos to be cultured were washed twice, transferred to droplets of medium in plastic Petri dishes containing $10 \mathrm{ml}$ light paraffin oil and cultured at $37^{\circ} \mathrm{C}$ (Brinster, 1963). In the experiments to determine the relationship between the levels of ATP in two-cell embryos obtained from mice of the QS strain and the subsequent development of the embryos to the blastocyst stage, twenty to thirty embryos were cultured in basic medium under an atmosphere of $5 \% \mathrm{CO}_{2}$ in air immediately or after incubation for 2 to $12 \mathrm{hr}$ in substrate-free medium to reduce ATP levels. In the experiments to determine ATP levels in embryos developing from the one-cell stage, embryos from both random-bred QS mice and hybrid mice were cultured in either basic medium or medium similar to that used by Whitten \& Biggers (1968), except that the concentration of sodium bicarbonate was reduced to $22.5 \mathrm{~mm}$ and bovine serum albumin to $3 \mathrm{mg} / \mathrm{ml}$ (Whitten, 1971). This modified medium contained $5.56 \mathrm{~mm}$-glucose in addition to lactate and pyruvate and has been found to support the development of hybrid one-cell embryos to the blastocyst stage (W. K. Whitten, personal communication). The embryos were cultured in droplets of media, as described above, under either an atmosphere of $5 \% \mathrm{CO}_{2}$ in air or an atmosphere of $5 \% \mathrm{O}_{2}: 5 \%$ $\mathrm{CO}_{2}: 90 \% \mathrm{~N}_{2}$ (Whitten, 1969). All media were equilibrated with the appropriate gas mixture before use.

Freshly collected or cultured embryos of normal morphological appearance were extracted with $50 \mu \mathrm{l}$ cold $2.5 \%$ perchloric acid and the levels of ATP assayed in 20- $\mu \mathrm{l}$ aliquots as described previously (Quinn \& Wales, 1971, 1973), duplicate estimations being made on each embryo extract. Storage of embryo extracts for $16 \mathrm{hr}$ at $4^{\circ} \mathrm{C}$ did not significantly alter the levels of ATP in the extracts.

The significance of the relationship between the levels of ATP in two-cell embryos and the proportion of these embryos developing to the blastocyst stage was estimated from the correlation coefficient. The percentage of two-cell 
embryos developing to the blastocyst stage was converted to angles before analysis. In the remaining two experiments, the effect of the different media and atmospheres on the levels of ATP in cultured QS and hybrid embryos was assessed by standard analysis of variance.

\section{RESULTS}

In thirty-six samples of freshly collected two-cell embryos from mice of the QS strain, the level of ATP present was $0.651 \pm 0.019 \mathrm{pmol} / \mathrm{embryo}$ (mean \pm S.E.) and the proportion of these embryos which developed to the blastocyst stage after $72 \mathrm{hr}$ culture in vitro was $59 \cdot 1 \pm 3 \cdot 5 \%$. The ATP values ranged from 0.378 to $0.858 \mathrm{pmol} / \mathrm{embryo}$ and between 11.8 and $90.9 \%$ of the embryos developed. Analysis of the results showed that there was a significant positive

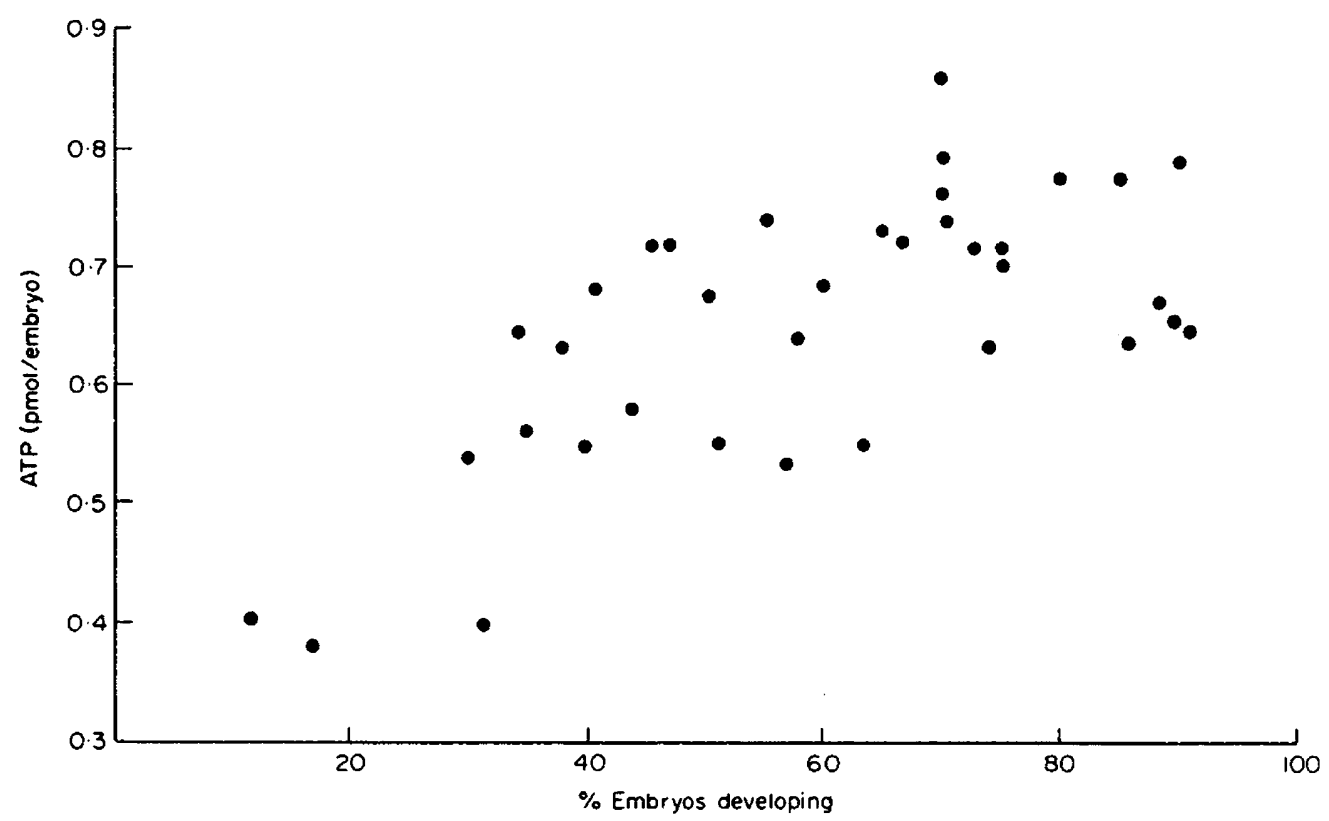

TExT-Fig. 1. The levels of ATP in freshly collected two-cell mouse embryos and their subsequent development in vitro to the blastocyst stage.

correlation $(r=0.66$, d.f. $=34, P<0.001)$ between the levels of ATP in the two-cell embryos and the proportion of these embryos developing to the blastocyst stage (Text-fig. 1). Using regression analysis, it was estimated that for each 0.1-pmol change in the level of ATP per embryo, there was a $7 \cdot 9 \pm 1.5$ change in angular response in the proportion of embryos developing to the blastocyst stage. This regression is approximately equivalent to a change of $13 \cdot 1 \pm 2 \cdot 6 \%$ in the proportion of embryos developing for each $0 \cdot 1$-pmol change in the level of ATP per embryo between the range of 25 and $75 \%$ development.

When two-cell embryos from QS mice were incubated in substrate-free medium for 2 to $12 \mathrm{hr}$ before subsequent culture, their levels of ATP progressively declined as the incubation time increased so that the level of ATP in 
embryos incubated for $12 \mathrm{hr}$ was approximately half that of freshly collected two-cell embryos (Table 1). The rate of decline in the ATP content of the embryos was greatest between 2 and $10 \mathrm{hr}$ after the start of the incubation. The proportion of these embryos which subsequently developed to the blastocyst stage in vitro after transfer to basic medium containing pyruvate and lactate

Table 1. Levels of ATP in two-cell mouse embryos after varying times of incubation in substrate-free medium and the subsequent development of the embryos to blastocysts in vitro

\begin{tabular}{c|c|c}
\hline $\begin{array}{c}\text { Hours in substrate-free } \\
\text { medium }\end{array}$ & $\begin{array}{c}A T P \\
\text { (pmollembryo) }\end{array}$ & $\begin{array}{c}\% \text { embryos } \\
\text { developed }\end{array}$ \\
\cline { 1 - 2 } 0 & $0.54 \pm 0.02$ & $53 \pm 5$ \\
2 & $0.55 \pm 0.01$ & $51 \pm 7$ \\
4 & $0.50 \pm 0.01$ & $44 \pm 10$ \\
6 & $0.44 \pm 0.03$ & $26 \pm 6$ \\
8 & $0.37 \pm 0.02$ & $13 \pm 6$ \\
10 & $0.29 \pm 0.01$ & $10 \pm 4$ \\
12 & $0.26 \pm 0.01$ & $2 \pm 1$ \\
\hline
\end{tabular}

Mean values of three replicates \pm S.E.M. are given.

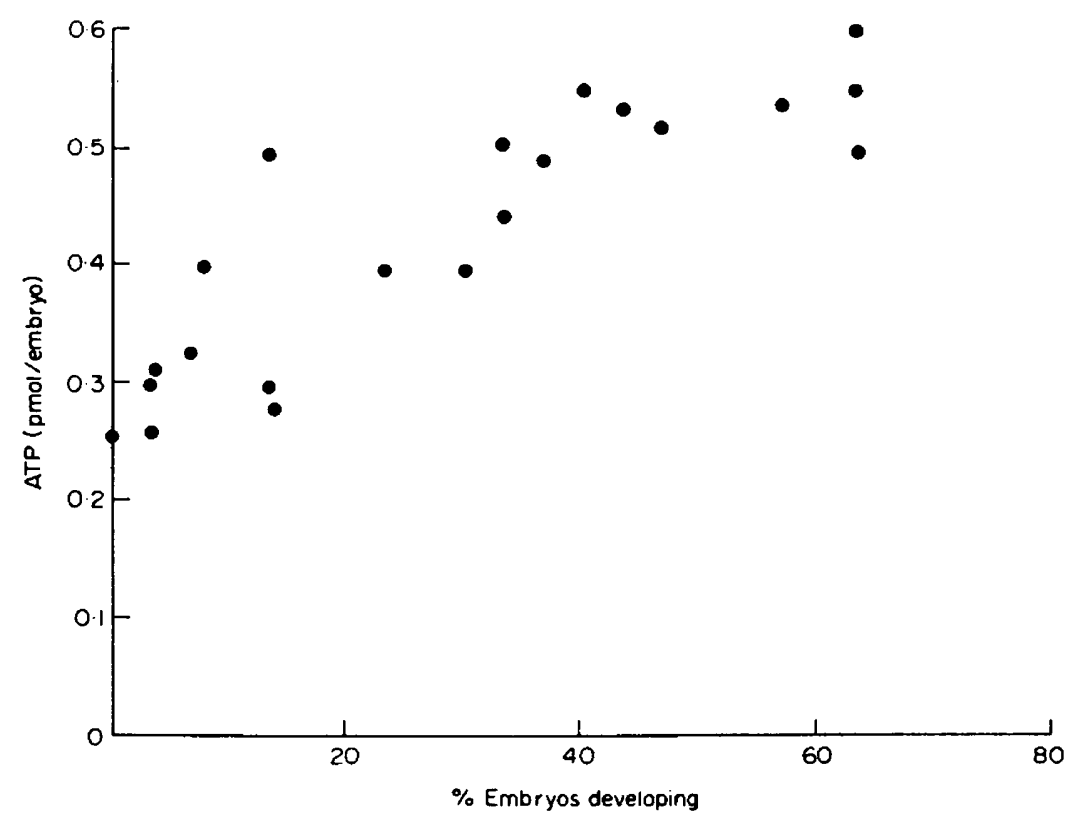

TEXT-FIc. 2. The levels of ATP in two-cell mouse embryos after incubation for up to $12 \mathrm{hr}$ in substrate-free medium and their subsequent development to the blastocyst stage.

as energy sources also decreased as the length of prior incubation in substratefree medium increased. The relationship between the ATP levels in the embryos after incubation in substrate-free medium and their subsequent development to the blastocyst stage is shown graphically in Text-fig. 2. As in the case of freshly collected embryos, there was a significant positive correlation between 
the levels of ATP in the two-cell embryos after incubation in substrate-free medium and the proportion of these embryos which subsequently developed to the blastocyst stage during culture $(r=0.88$, d.f. $=19, P<0.001)$. Expressing this relationship in terms of a regression coefficient, there was a $12.0 \pm$ 1.5 angular decrease in the proportion of embryos which developed to the blastocyst stage for each $0 \cdot 1$-pmol decrease in the level of ATP per embryo at the two-cell stage. This corresponds to a percentage decrease in development of $20 \cdot 1 \pm 2 \cdot 5$ for each $0 \cdot 1-\mathrm{pmol}$ decrease in the amount of ATP per embryo between the range of 25 and $75 \%$ development.

In the next experiment, one-cell embryos from the QS strain and $F_{1}$ hybrids were collected and cultured for $24 \mathrm{hr}$ in basic medium (Medium 1) or the medium modified for the culture of one-cell embryos described in the Materials and Methods section (Medium 2). The embryos were cultured in these media

Table 2. Levels of ATP in embryos from two groups of mice which developed from the one- to two-cell stages during culture for $24 \mathrm{hr}$ in two different media and under two different atmospheres

\begin{tabular}{c|c|c|c}
\hline \multicolumn{2}{c|}{ Conditions of culture } & \multicolumn{2}{c}{$A T P($ pmol/embryo $)$} \\
\hline \multicolumn{1}{c|}{ Atmosphere } & Medium & $F_{1}$ hybrid & QS strain \\
\hline $5 \% \mathrm{CO}_{2}: 95 \%$ air & 1 & $0.83(93)$ & $0.73(61)$ \\
& 2 & $1.05(86)$ & $0.98(34)$ \\
$5 \% \mathrm{CO}_{2}: 5 \% \mathrm{O}_{2}: 90 \% \mathrm{~N}_{2}$ & 1 & $0.79(94)$ & $0.72(46)$ \\
& 2 & $1.06(89)$ & $0.93(47)$ \\
\hline Freshly collected & 1-cell & 0.97 & 0.93 \\
& 2 -cell & 0.73 & 0.68 \\
\hline
\end{tabular}

Mean values of three replicates for each group of embryos are given with the percentage of embryos developing during culture shown in parentheses. See text for details of media. The S.E. for differences between means = 0.016 (d.f. $=36$ ).

under an atmosphere of either $5 \% \mathrm{CO}_{2}$ in air or $5 \% \mathrm{CO}_{2}: 5 \% \mathrm{O}_{2}: 90 \% \mathrm{~N}_{2}$. At the end of the culture period, the levels of ATP in the embryos which had developed from the one- to two-cell stage were assayed and compared to the amounts of ATP in freshly collected one- and two-cell embryos. The data from three replicates of each group of embryos are given in Table 2. A greater proportion of hybrid than random-bred embryos developed to the two-cell stage during the culture period. Within each group of mice, however, there was no consistent trend in the effects of either media or gas phase on the proportion of embryos developing. The amount of ATP in the cultured hybrid two-cell embryos was 7 to $14 \%$ more than that in QS embryos which cleaved, but there was no detectable difference between the two groups of mice in the levels of ATP in freshly collected one- and two-cell embryos. Medium 2, which was of lower tonicity than Medium 1 and contained glucose and extra albumin, was able to maintain significantly $(P<0.01)$ higher levels of ATP in both groups of embryos which developed under either atmosphere. Nevertheless, embryos from both groups of mice which developed to the two-cell stage in 
either medium had higher levels of ATP than freshly collected two-cell embryos. In the case of embryos cultured in Medium 2, the levels of ATP in hybrid embryos cultured to the two-cell stage were higher than the levels in freshly collected one-cell hybrid embryos. In the QS embryos, there was no significant difference between the amounts of ATP in cultured and freshly collected one-cell embryos.

Most of the embryos from the QS strain of mice failed to develop past the two-cell stage under either atmosphere or in either medium during subsequent culture. With hybrid embryos, equal development occurred up to the morula stage in both media and under both atmospheres, but none of the embryos cultured in Medium 1 developed into blastocysts. The remaining experiment was, therefore, confined to measuring the levels of ATP during development in vitro of hybrid embryos cultured in Medium 2, using different amounts of $\mathrm{O}_{2}$ in the atmosphere. The results are given in Table 3. The levels of ATP in

Table 3. Levels of ATP in cultured embryos from $F_{1}$ hybrid mice developing from the one-cell to blastocyst stage under two different atmospheres

\begin{tabular}{l|c|c}
\hline \multirow{2}{*}{$\begin{array}{c}\text { Stage of development } \\
\text { at time of assay }\end{array}$} & \multicolumn{2}{|c}{$A T P($ pmol/embryo) } \\
\cline { 2 - 3 } \multicolumn{1}{c|}{$5 \% \mathrm{CO}_{2}: 95 \%$ air } & $5 \% \mathrm{CO}_{2}: 5 \% \mathrm{O}_{2}: 90 \% \mathrm{~N}_{2}$ \\
\hline 2-cell & $0.82(87)$ & $0.79(87)$ \\
4-, 8-cell & $1.25(69)$ & $1.25(65)$ \\
Morula & $0.85(51)$ & $0.92(51)$ \\
Blastocyst & $0.60(26)$ & $0.72(20)$ \\
\hline
\end{tabular}

Mean values of two replicates are given with the percentage of embryos developing shown in parentheses. The S.E. for differences between means $=0.036$ (d.f. $=16$ ).

embryos which developed during culture increased during the first $48 \mathrm{hr}$ of culture from the one-cell stage and then began to decline. An effect of the different atmospheres on the levels of ATP in developing embryos only became apparent at the morula and blastocyst stages. In spite of the higher levels of ATP in embryos cultured under an atmosphere of $5 \% \mathrm{CO}_{2}: 5 \% \mathrm{O}_{2}: 90 \% \mathrm{~N}_{2}$, the proportion of these embryos which reached the blastocyst stage was not greater than that of embryos cultured under the atmosphere containing more oxygen. Under either atmosphere, only one in four to five of the one-cell embryos initially cultured reached the blastocyst stage.

\section{DISCUSSION}

In the present experiments, the proportion of freshly collected two-cell mouse embryos developing in vitro to the blastocyst stage was similar to that reported previously for embryos cultured under similar conditions (Brinster, 1965c; Wales, 1970). Normally, the majority of cultured two-cell embryos can be expected to develop to the blastocyst stage and if this does not occur, the cause is usually attributed to some defective technique in the routine of the culture laboratory (see Whittingham, 1971). From the results reported here, however, 
it is obvious that in some cases, embryos with a lower level of ATP than normal do occur and fewer of these embryos than normal develop during culture.

Experiments with other cells have shown that the levels of ATP can influence important cellular events involved in development. Freudenberg \& Mager (1971) have reported that a decline in the ATP content of rabbit reticulocytes and Landschütz ascites tumour cells is accompanied by arrested protein synthesis in these cells. Corroborative evidence for a similar mechanism in mouse embryos is provided by the findings that, when pyruvate and lactate are combined in the culture medium at concentrations optimal for development, the incorporation of substrate carbon into protein by two-cell embryos is greater than in the presence of either substrate alone (Wales \& Whittingham, 1973b). A combination of pyruvate and lactate also maintains higher levels of ATP in cultured one- and two-cell embryos than either substrate alone (Quinn \& Wales, 1973).

The suppression of protein synthesis in cultured cells reported by Freudenberg \& Mager (1971) appears to be influenced more by the products of the splitting of ATP (ADP and AMP) interfering with the process of peptide-chain elongation than by a direct effect of ATP changes. In the one- and two-cell mouse embryo, the levels of ADP are extremely low and since the ATP/ ADP pool in freshly collected embryos remains relatively constant throughout preimplantation development (Quinn \& Wales, 1973), a small decrease in the concentration of ATP would result in a relatively large increase in the level of ADP. This in turn could have marked effects on protein synthesis. Although protein synthesis in the mouse embryo is low during the early stages of development, the results of Thomson \& Biggers (1966) suggest that a small amount is required for the operation of the mitotic mechanism. Any inhibitory influence of low ATP levels on protein synthesis amplified through a large change in the level of ADP would thus be expected to affect embryonic development adversely.

The superiority of a medium which contains glucose and a high concentration of albumin in maintaining the levels of ATP in cultured one-cell embryos from both hybrid and random-bred strains of mice could be related to the beneficial effect of these compounds on the metabolism of the embryo. The addition of commercial crystalline serum albumin to substrate-free medium is beneficial to the development of eight-cell mouse embryos (Brinster \& Thomson, 1966; Wales \& Whittingham, 1973a). Although this effect could be due to the utilization of exogenous protein for the metabolic requirements of the embryo, it appears that such utilization is low during the early cleavage stages (Brinster, 1971) and is unnecessary for the development of hybrid two-cell embryos when energy substrates are present (Cholewa \& Whitten, 1970). Thus, any influence of high concentrations of albumin on the levels of ATP in embryos is more likely to be related to a protective action, rather than a direct metabolic effect of the macromolecule. Although the mouse embryo cannot rely wholly on glucose to support development up to the eight-cell stage (Brinster, 1965a; Brinster \& Thomson, 1966), the earlier stages of development can incorporate glucose carbon (Wales \& Brinster, 1968; Brinster, 1969) and this does contribute to the maintenance of ATP levels (Quinn \& Wales, 1973). 
The observed superiority of one-cell hybrid mouse embryos over randombred embryos in developing during culture in spite of the absence of any significant difference in the levels of ATP between the two groups of embryos did not conform with the results obtained in the initial studies where significant correlations were obtained between the amount of ATP in early embryos and the proportion of the embryos developing in vitro. Although the hybrid embryos cultured to the two-cell stage had higher levels of ATP than similar embryos from QS mice, the amounts of ATP in embryos from both strains of mice were greater than those in freshly collected two-cell embryos. Thus, the results obtained during culture of the one-cell embryos of both strains of mice suggest that the correlation between ATP content and growth in vitro of freshly collected randomly bred two-cell embryos cannot be extrapolated to forecast the relationship between ATP content and development of other embryos. The level of ATP in the embryo is related to the rate of synthesis and breakdown of the nucleotide, either of which may vary between strains and with changes in the environment. In addition, Epstein \& Daentl (1971) have suggested that the ATP of mouse embryos may be compartmentalized. Perhaps a difference in the dynamics of the transfer between adenine nucleotide pools could also be responsible for the changing relationship between ATP content and development of embryos.

Some difficulty has been experienced by various investigators in culturing one-cell mouse embryos to the blastocyst stage (sce Whitten, 1971). In the present experiments where the culture-dish method of Brinster (1963) has been used, 20 to $26 \%$ of hybrid one-cell embryos developed into blastocysts. Whitten (1971) has reported that $100 \%$ of one-cell embryos develop into blastocysts when the atmosphere contains $5 \% \mathrm{O}_{2}$ but the proportion of embryos developing decreases rapidly as the $\mathrm{O}_{2}$ concentration is raised. Although different amounts of $\mathrm{O}_{2}$ in the culture atmosphere did not affect development of embryos in the present experiments, the beneficial effects of low $\mathrm{O}_{2}$ tension reported by Whitten (1971) may be related to the present finding that one-cell hybrid embryos devcloping into blastocysts contain higher levels of ATP if cultured under an atmosphere containing $5 \%$ rather than one containing $20 \% \mathrm{O}_{2}$.

The low number of cultured one-cell embryos developing into blastocysts in the present experiments as compared to those reported by Whitten (1971) could be due to differences between strains of mice used in the respective experiments (sce Whittingham, 1971). The purity of components of the culture system could be important in promoting development during culture in vitro. In particular, the purity of the water used to make up the culture medium can affect the development of mouse embryos in vitro (Whittingham, 1971). Water purity was unlikely to be responsible for the poor development of one-cell hybrid embryos reported here as all media in these experiments were made from five times glass-distilled water.

\section{AGKNOWLEDGMENTS}

The authors are indebted to Professor C. W. Emmens for interest and criticism. This work was aided by a grant from the Australian Research Grants Commit- 
tee. One of us (P.Q.) was supported by an Australian Wool Board PostGraduate Studentship.

\section{REFERENGES}

Brinster, R. L. (1963) A method for in vitro cultivation of mouse ova from two-cell to blastocyst. Expl Cell Res. 32, 205.

BRINSTER, R. L. (1965a) Studies on the development of mouse embryos in vitro. II. The effect of energy source. 7. exp. Zool. 158, 59.

BRINSTER, R. L. (1965b) Lactate dehydrogenase activity in the preimplanted mouse embryo. Biochim. biophys. Acta, 110, 439.

Brinster, R. L. (1965c) Studies on the development of mouse embryos in vitro. IV. Interaction of energy sources. 7. Reprod. Fert. 10, 227.

BRINSTER, R. L. (1969) Incorporation of carbon from glucose and pyruvate into the preimplantation mouse embryo. Expl Cell Res. 58, 153.

BRINSTER, R. L. (1971) Uptake and incorporation of amino acids by the preimplantation mouse embryo. F. Reprod. Fert. $27,329$.

Brinster, R. L. \& Thomson, J. L. (1966) Development of eight-cell mouse embryos in vitro. Expl Cell Res. 42, 308.

Gholewa, J. A. \& Whitren, W. K. (1970) Development of two-cell mouse embryos in the absence of a fixed nitrogen source. F. Reprod. Fert. 22, 553.

Epstein, G. J. \& Daentl, D. L. (1971) Precursor pools and RNA synthesis in preimplantation mouse embryos. Devl Biol. 26, 517.

FreudenberG, H. \& MAGER, J. (1971) Studies on the mechanism of the inhibition of protein synthesis induced by intracellular ATP depletion. Biochim. biophys. Acta, 232, 537.

QuinN, P. \& Wales, R. G. (1971) Adenosine triphosphate content of preimplantation mouse embryos. 7. Reprod. Fert. 25, 133.

Quinn, P. \& Wales, R. G. (1973) The effect of culture in vitro on the levels of adenosine triphosphate in preimplantation mouse embryos. 7. Reprod. Fert. 32, 231.

Thomson, J. L. \& Biggers, J. D. (1966) The effect of inhibitors of protein synthesis on the development of mouse embryos in vitro. Expl Cell Res. 41, 411.

WaLEs, R. G. (1970) Effects of ions on the development of the pre-implantation mouse embryo in vitro. Aust. 7. biol. Sci. 23, 421.

Wales, R. G. \& Brinster, R. L. (1968) The uptake of hexoses by pre-implantation mouse embryos in vitro. F. Reprod. Fert. 15, 415.

Wales, R. G. \& Whittingham, D. G. (1973a) Development of eight-cell mouse embryos in substratefree medium. 7. Reprod. Fert. 32, 316 (Abstr.).

Wales, R. G. \& Whitringham, D. G. (1973b) The metabolism of specifically labelled lactate and pyruvate by two-cell mouse embryos. 7. Reprod. Fert. 33, 207.

Whitten, W. K. (1969) The effect of oxygen on cleavage of nouse eggs in vitro. In: Abstracts of 2 nd Annual Meeting of the Society for the Study of Reproduction, p. 29. Available from Dr G. B. Marion, Dept of Animal Industries, S. Illinois University.

WhItTEN, W. K. (1971) Nutrient requirements for the culture of preimplantation embryos in vitro. In: Advances in the Biosciences, Vol. 6. Ed. G. Raspe. Pergamon Press, Oxford.

Whitren, W. K. \& Biggers, J. D. (1968) Complete development in vitro of the preimplantation stages of the mouse in a simple chemically defined medium. F. Reprod. Fert. 17, 399.

Whittingham, D. G. (1971) Culture of mouse ova. F. Reprod. Fert. Suppl. 14, 7.

Whittingham, D. G. \& Biggers, J. D. (1967) Fallopian tube and early cleavage in the mouse. Nature, Lond. 213, 942. 